\title{
ANALYSIS OF CARBON AND NUTRIENT STORAGE OF DRY TROPICAL FOREST OF CHHATTISGARH USING SATELLITE DATA
}

\author{
Tarun Kumar Thakur \\ Department of Environmental Science, Indira Gandhi National Tribal University, Amarkantak, M. P. \\ eMail ID: tarun_2711@yahoo.co.in; www.igntu.nic.in
}

KEY WORDS: Forest dynamics, carbon sequestration, nutrient pattern, RS and GIS

\begin{abstract}
The purpose of this study was to characterize the carbon, nitrogen, phosphorus and potassium in the Barnowpara Sanctuary, Raipur district, Chhattisgarh, India through the use of satellite remote sensing and GIS The total storage of nutrients in vegetation (OS+US+GS) varied from 105.1 to $560.69 \mathrm{~kg} \mathrm{ha}^{-1}$ in $\mathrm{N}, 4.09 \mathrm{~kg} \mathrm{ha}^{-1}$ to $49.59 \mathrm{~kg} \mathrm{ha}^{-1}$ in P, $24.59 \mathrm{~kg} \mathrm{ha}^{-1}$ to $255.58 \mathrm{~kg}$ $\mathrm{ha}^{-1}$ for $\mathrm{K}$ and 7310 to $4836 \mathrm{~kg} \mathrm{ha}^{-1}$ for $\mathrm{C}$ in different forest types. They were highest in Dense mixed forest and lowest in Degraded mixed forest. The study also showed that NDVI and carbon storage was strongly correlated to Shannon Index and species richness thus it indicates that the diversity of forest type play a vital role in carbon accumulation. The study also developed reliable regression model for the estimation of LAI, biomass, NPP, C \& N storage in dry tropical forests by using NDVI and different vegetation indices, which can be derived from fine resolution satellite data. The study shows that dry tropical forests of Central India are quite immature and not in standing state and have strong potential for carbon sequestration. Both quantitative and qualitative information derived in the study helped in evolving key strategies for maintaining existing $\mathrm{C}$ pools and also improving the $\mathrm{C}$ sequestration in different forest types. The study explores the scope and potential of dry tropical forests for improving $\mathrm{C}$ sequestration and mitigating the global warming and climatic change.
\end{abstract}

\section{INTRODUCTION}

Tropical forests are one among the rich and complex terrestrial ecosystems store approximately $50 \%$ of the worlds living terrestrial carbon and also harbor variety of life forms. They are important both ecologically and economically, and have direct bearing on regulating the biosphere climate and also meeting the diverse needs of biomass. However, during last few decades increased anthropogenic perturbations, over grazing and alarming rates of land transformation caused severe environmental degradation and affected the biogeochemical cycle, biological diversity, productivity and consequently altered the global ecology (King et al., 1997). The quantitative as well as qualitative information on land use pattern and vegetation status are necessary for formulating useful policies for timber harvesting, conserving biodiversity, carbon sequestration, combating environmental hazards and sustainable management of the resources. The data on biomass and forest productivity are scarce in many important tropical forests.

Life-supporting systems on planet earth are facing alarming threats due to rapid declining of diversity and complexity of living organisms (Stoms and Estes 1993). Chhattisgarh state covered with more than $44 \%$ of the geographical area under tropical forests has strong potential for carbon sequestration. However, increased anthropogenic activities have led to degradation of virgin forests in last few decades. According to the recent report published by Forest Survey of India (FSI) on state of forests of India, there is a net loss of $189 \mathrm{~km}^{2}$ of forests occurred between 2005 and 2011 in Chhattisgarh. Further a fairly good amount $(3.5-5 \%)$ of dense forests are converted into open and degraded forests during this period.

The amount, rate, and intensity of land use and land cover are very high in the dry tropical forest ecosystems of Chhattisgarh, India. There is a dire need to evolve sustainable land use practices for conserving diversity, enhancing productivity, carbon sequestration and improving biogeochemical cycles. The present study was conducted to analyzed the carbon and nutrients storage of a dry tropical forest ecosystem. Satellite remote sensing and GIS techniques were used for the characterisation of land use, structure, and diversity.

\section{MATERIALS AND METHODS}

\subsection{Study area}

This study was carried out in a watershed representing a dry tropical forest ecosystem in part of Barnowpara Sanctuary, Raipur Forest Division, Chhattisgarh, India during 2004-2007. The Wildlife Sanctuary was established in 1976 under Wildlife Protection Act of 1972, covering an area of 245 sq $\mathrm{km}$. About $76 \%$ of the study area/watershed falls in the sanctuary. The watershed comprises an area of $165.64 \mathrm{~km}^{2}$, of which different forests cover more than $70 \%$ area. It is situated between $21^{\circ} 20^{\prime}$ to $21^{\circ} 28^{\prime}$ north latitudes and $82^{\circ} 21^{\prime}$ to $82^{\circ} 26^{\prime}$ east longitudes. The climate is dry, humid, and 
tropical and consists three major seasons: rainy, winter, and summer. The mean annual rainfall of the study area ranges from 1200-1350 mm. The mean annual temperature of the study area is about $26.5^{\circ} \mathrm{C}$, which begins to increase in March to May. The highest temperature goes beyond $41.8^{\circ} \mathrm{C}$ in May and lowest below $12.7^{\circ} \mathrm{C}$ in December. The soils of the study area are quite variable in their physical and chemical properties and fall three classes, Inceptisols, Alfisols and Vertisols (Soil Survey Staff 1960).

\subsection{Materials}

IRS ID LISS III cloud-free digital data was procured from the NRSA Data Centre in Hyderabad, India. The data covers the entire study area of Barnowpara and its surrounding environs. Digital analysis was performed on ERDAS Imagine (Version 8.6) Image analysis software and the ancillary data collected from SOI topographical maps was analyzed in ARC-GIS (Version 8.2). The base map was drawn from a survey of India topographical $64 \mathrm{~K} / 7$ and $64 \mathrm{~K} / 11$ on 1:50,000 scale and used for geometric rectification of satellite data. A reconnaissance survey was made to recognize important vegetation types in different physiographic units and related to the tonal variations on the satellite image for accurate classification.

Stratified random sampling approach was followed for conducting phyto-sociological survey and assessing carbon and nitrogen storages. Ground sampling was done by randomly laying $20 \mathrm{~m} \mathrm{X} 20 \mathrm{~m}$ quadrates. The component wise samples viz., foliage, bole, branches and roots were collected and analyzed for total carbon and N, P and K. Nitrogen and carbon pools in vegetation were quantified by multiplying the biomass of each component with their respective $\mathrm{N}$ and $\mathrm{C}$ concentration of that component. Total vegetation $\mathrm{C}$ and $\mathrm{N}$ was obtained by adding tree, shrub and herbaceous component.

\subsection{Nutrient and $C$ analysis in vegetation}

In order to measure the nutrient distribution in different forest types, component samples of trees, shrubs and herbs were randomly collected from five sampling plots (quadrates) of each forest type, which were used in measurement of biomass and net productivity.

2.3.1 Estimation of $\mathbf{N}, \mathbf{P}$, and $\mathbf{K}$ : In overstorey, the stem, branch, root and foliage components were randomly collected from different trees and crown positions. Similarly, in case of understorey and groundstorey vegetation, shoot, foliage and roots components were collected and dried. Composite samples of each component were prepared in different layers of vegetation and oven dried. The dried samples were ground in Wiley mill and passed through $2 \mathrm{~mm}$ sieve to obtain fine powder, which was chemically analyzed in triplicate samples for different nutrients (N, P and K). Nitrogen was determined by Micro-Kjeldhal method (Jackson, 1958). The 0.1g plant sample was digested in 10-ml conc. $\mathrm{H}_{2} \mathrm{SO}_{4}$ with catalyst mixture of $\mathrm{Na}_{2} \mathrm{SO}_{4}$ and $\mathrm{CuSO}_{4}$ (5:1 by wt.) followed by distillation and titration. The total phosphorous was determined by using spectrophotometer (Olsen et al., 1954) and vando-molybdate yellow reagent procedure. In this procedure $0.5 \mathrm{gm}$ sample was digested in $10 \mathrm{ml}$ diacid $\left(\mathrm{HNO}_{3}\right.$ and $\mathrm{HClO}_{4}$ 9:4) and then using yellow reagent (Ammonium molybdate+Ammonium meta-vandate + nitric acid) in aliquots. The total potassium was determined by using flame photometer.

2.3.2 Estimation of carbon: Carbon concentration was estimated by ash content method (Negi et al., 2003). In this method oven dried plant components (stem, branch, root and leaves) were burnt in electric furnace at $400^{\circ} \mathrm{C}$ temperatures. Ash content (inorganic elements in the form of oxides) left after burning was weighed and carbon concentration was calculated by using the following equation

Carbon $\%=100$-Ash weight + molecular weight of $\mathrm{O}_{2}$ (53.3) in $\left(\mathrm{C}_{6} \mathrm{H}_{12} \mathrm{O}_{6}\right)$.

\subsection{Standing state of nutrients and $\mathrm{C}$ in different forest types}

Nutrient (N, P and $\mathrm{K}$ ) and $\mathrm{C}$ storage in different components of tree, shrub and herb layers for each forest were estimated by the product of nutrient/C concentration and their respective biomass values (2003). The component wise nutrient status was computed for different layers of each forest type and extrapolated on $\mathrm{Mg} \mathrm{ha}^{-1}$ basis. All the components nutrient/C values were summed to obtain nutrient/C storage. The nutrient content of trees (by components), shrubs, herbaceous layers and fine roots were summed to derive total nutrient status in each sample plot (quadrate) for a given forest type. Mean nutrient content of the five sample plots represented the standing nutrient and $\mathrm{C}$ status of a given forest type. In order to obtain the total existing nutrient status of different forest type, the mean nutrient values were multiplied with their respective areas of forest types derived from satellite data.

The following expression is used in the present study to quantify the nutrient and carbon status of different forest types

$\mathrm{Ty}_{\mathrm{ni}}=\sum_{i=1}^{n} \mathrm{Ty}_{\mathrm{ai}} *\left(\mathrm{O}_{\mathrm{ni}}+\mathrm{U}_{\mathrm{ni}}+\mathrm{G}_{\mathrm{ni}}\right)$

Where

$T y_{n i}=$ Nutrient status of $i^{\text {th }}$ forest type

$\mathrm{Ty}_{\mathrm{ai}}=$ Area of $\mathrm{i}^{\text {th }}$ forest type

$\mathrm{O}_{\mathrm{ni}}=$ nutrients in overstorey, $\mathrm{U}_{\mathrm{ni}}=$ nutrients in understorey, $\mathrm{G}_{\mathrm{ni}}=$ nutrients in groundstorey of $\mathrm{i}^{\text {th }}$ forest type

$\mathrm{O}_{\mathrm{ni}}=\left(\mathrm{Sm}_{\mathrm{ni}}+\mathrm{Br}_{\mathrm{ni}}+\mathrm{Lf}_{\mathrm{ni}}+\mathrm{CRt}_{\mathrm{ni}}+\mathrm{FRT}_{\mathrm{ni}}\right)$

$\mathrm{U}_{\mathrm{ni}}=\left(\mathrm{S}_{\mathrm{ni}}+\mathrm{Lf}_{\mathrm{ni}}+\mathrm{Rt}_{\mathrm{ni}}\right)$

$\mathrm{G}_{\mathrm{ni}}=\left(\mathrm{Lf}_{\mathrm{ni}}+\mathrm{Rt}_{\mathrm{ni}}\right)$

Where

$\mathrm{Sm}_{\mathrm{ni}}=$ Stem nutrients, $\mathrm{Br}_{\mathrm{ni}}=$ Branch nutrients, $\mathrm{Lf}_{\mathrm{ni}}=$ Leaf nutrients, $\mathrm{Rt}_{\mathrm{ni}}=$ Root nutrients $\mathrm{CRt}_{\mathrm{ni}}=$ Coarse root nutrients, $\mathrm{FRT}_{\mathrm{ni}}=$ Fine root nutrients, $\mathrm{W}_{\mathrm{bi}}=$ Wood nutrients corresponding to ith forest type

$\mathrm{TN}=\mathrm{Ty}_{\mathrm{ni}}+\mathrm{Ty}_{\mathrm{nj}}+\mathrm{Ty}_{\mathrm{nk}} \cdots \cdots \cdots \mathrm{Ty}_{\mathrm{nn}}$

$\mathrm{TN}=$ Total standing nutrients, Ty ${ }_{n i . . n n}=$ Nutrients in $i^{\text {th }}, \mathrm{j}^{\text {th }}, \mathrm{k}^{\text {th }}$ ------n ${ }^{\text {th }}$ forest types

The uptake of nitrogen and $\mathrm{C}$ sequestration was calculated as the product of N/C concentrations with their respective dry biomass production values of each component of a vegetation layer in a given forest type. In order to obtain the total nutrient 
uptake of different forest types in study area, the mean nutrient uptake values were multiplied with their respective areas of forest types, which were derived from satellite data.

\section{RESULTS AND DISCUSSION}

\subsection{Total $\mathrm{N}$ and $\mathrm{C}$ storage in vegetation}

Conjunctive use of satellite remote sensing, ground techniques and ecosystem simulation models have strong potential in studying the biogeochemical cycles at large spatial scales. Only limited attempts were made to understand $\mathrm{C}$ and $\mathrm{N}$ dynamics through conjunctive use of satellite remote sensing and ecosystem simulation models (Verstrate and Pinty, 1991; Melillo et al., 1993). Foody et al (1996) identified terrestrial carbon sinks by classification of successional stages in regenerating tropical forests from Landsat TM data.

The total $\mathrm{N}$ and $\mathrm{C}$ storage of vegetation (OS+US+GS) varied from $105.1 \mathrm{~kg} \mathrm{ha}^{-1}$ to $560.69 \mathrm{~kg} \mathrm{ha}^{-1}$ and $7310 \mathrm{~kg} \mathrm{ha}^{-1}$ to 4836 $\mathrm{kg} \mathrm{ha}{ }^{-1}$ in different forest types (Table 1). $\mathrm{N}$ storage was highest in Dense mixed forest followed by Sal mixed, Open mixed forest, Teak forest and lowest in Degraded mixed forest. However, $\mathrm{C}$ storage was highest in Dense mixed forest and lowest in Degraded mixed forest. $\mathrm{N}$ and $\mathrm{C}$ contents were statistically at par with each other in Sal mixed and Open mixed forest. Total $\mathrm{N}$ and $\mathrm{C}(\mathrm{OS}+\mathrm{US}+\mathrm{GS})$ also varied significantly in different forest types. For total nitrogen, tree, shrub and herb layers contributed 85.13-95.23\%, 1.39-9.04 \% and $0.48-1.38 \%$, respectively. Similarly, for total C storage, overstorey, understorey and groundstorey contributed 81.67$95.02 \%, 4.69-17.37 \%$ and $0.28-0.96 \%$, respectively (Table 1 ). In India, only few attempts were made in this direction to quantify biomass, carbon storage and flux rates in tropical ecosystems (Jha 1990; Singh and Singh, 1991; Ravan, 1994; Roy et al., 1993; Swamy, 1998). In present study use of satellite data was quite promising in understanding the $\mathrm{N}, \mathrm{P}, \mathrm{K}$ and $\mathrm{C}$ distribution.

The present estimates of carbon storage are in much lower in range when compared to the other estimates made in different tropical forests (Brown and Lugo, 1982; Brown et al., 1994; Swamy, 1998; Field and Kaduk, 2004). Brown and Lugo (1982) reported 46 to $183 \mathrm{Mg} \mathrm{C} \mathrm{ha}^{-1}$ for variety of tropical dry forests of the world. Similarly, Swamy (1998) observed 94.3 to $190.96 \mathrm{Mg} \mathrm{C}^{-1}{ }^{-1}$ in semi-evergreen forests of Karnataka, India. Brown et al. (1994) also reported 95 to $157 \mathrm{Mg} \mathrm{C} \mathrm{ha}^{-1}$ for different tropical forests of Malaysia. The lower carbon storage in dry tropical forests of the present study area was ascribed to presence of poor stand density and relatively lower proportion of trees in higher diameter classes compared to above forests. Moreover, the forests are not fully mature and not in standing state in the study area, whereas they were in standing state and contain a relatively better representation of large size trees resulted in higher carbon storage in other tropical forests.

Among several vegetation indices tested, NDVI (Plate 1) is strongly correlated with $\mathrm{C}$ and $\mathrm{N}$ densities in the forests. This might be due to NDVI is a greenness index, strongly correlated with biomass, both $\mathrm{C}$ and $\mathrm{N}$ pools directly depend on the amount of biomass.

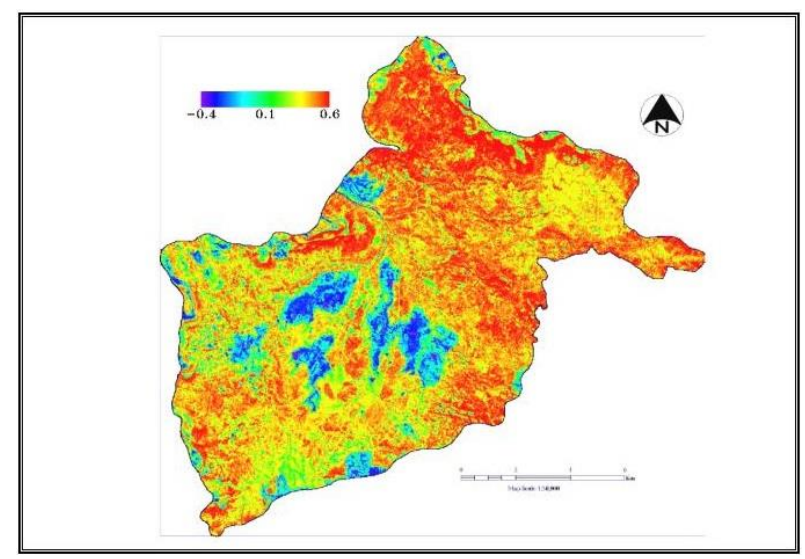

Plate 1: NDVI map of the study area

In the present study, the concentration of nutrients $(\mathrm{N}, \mathrm{P}$ and $\mathrm{K}$ ) in vegetation followed the order: foliage > branch> root> stem> fine root. Similar trends have been reported by several workers (Feeler, 1980; Chaturvedi and Singh, 1987; Lodhiyal et al., 1995; Lodhiyal and Lodhiyal, (1997).

Table 1: Total $\mathrm{N}$ and $\mathrm{C}$ content of overstorey, understorey and groundstorey $(\mathrm{Kg} / \mathrm{ha})$

\begin{tabular}{|l|c|c|c|c|c|c|c|c|}
\hline $\begin{array}{l}\text { Forest } \\
\text { type }\end{array}$ & \multicolumn{2}{|c|}{ Overstorey } & \multicolumn{2}{|c|}{$\begin{array}{c}\text { Understore } \\
\text { ynd }\end{array}$} & $\begin{array}{c}\text { Groundstore } \\
\text { y }\end{array}$ & \multicolumn{2}{|c|}{ GT } \\
\cline { 2 - 9 } & $\mathbf{N}$ & $\mathbf{C}$ & $\mathbf{N}$ & $\mathbf{C}$ & $\mathbf{N}$ & $\mathbf{C}$ & $\mathbf{N}$ & $\mathbf{C}$ \\
\hline $\begin{array}{l}\text { Teak } \\
\text { rest }\end{array}$ & 360.3 & 36890 & 23.46 & 2880 & 1.87 & 115 & 385.71 & 39885 \\
\hline $\begin{array}{l}\text { Sal } \\
\text { ixed }\end{array}$ & 425.1 & 29480 & 36.64 & 3760 & 4.2 & 195 & 465.93 & 33435 \\
\hline $\begin{array}{l}\text { Dense } \\
\text { ixed }\end{array}$ & 534 & 45340 & 23.34 & 2890 & 3.39 & 140 & 560.69 & 48370 \\
\hline $\begin{array}{l}\text { Open } \\
\text { ixed }\end{array}$ & 390 & 29600 & 39.21 & 4990 & 4.25 & 223 & 433.63 & 34813 \\
\hline $\begin{array}{l}\text { Degrad } \\
\text { I mixed }\end{array}$ & 89.47 & 5620 & 14.16 & 1650 & 1.47 & 73 & 105.1 & 7343 \\
\hline $\begin{array}{l}\text { CD at } \\
\text { \% }\end{array}$ & 31.47 & 3.74 & 10.36 & 1.44 & 0.79 & 0.032 & 38.15 & 5.212 \\
\hline
\end{tabular}

\subsection{Correlation and regression relationships between vegetation indices, $\mathrm{N}$ and $\mathrm{C}$ storage}

It is evident from the results that $\mathrm{N}$ storage was positively correlated with NDVI, AVI, PVI, SAVI and RVI indices, whereas $\mathrm{C}$ storage was significant correlated with NDVI and SAVI. Among the different vegetation indices, NDVI was strongly correlated with $\mathrm{C}$ and $\mathrm{N}$ storage, which were found to be highly significant both at 5 and 1 percent level as compared to other vegetation indices. NDVI was best fitted for both C \& $\mathrm{N}$ storage in dry tropical forest of Chhattisgarh. Regression relationships were drawn between mean NDVI, $\mathrm{C}$ and $\mathrm{N}$ storage (Pooled data) in different forest types and results are 
presented in Figs. 1 and 2. Both $\mathrm{C}$ and $\mathrm{N}$ storage were significantly correlated to mean NDVI. Among the different vegetation indices, the better regression relationships were observed in NDVI. There was a positive correlation between mean NDVI and $\mathrm{C}$ and $\mathrm{N}$ storage (pooled data of OS+US) for the study area and all the vegetation types (Plate 2,3).

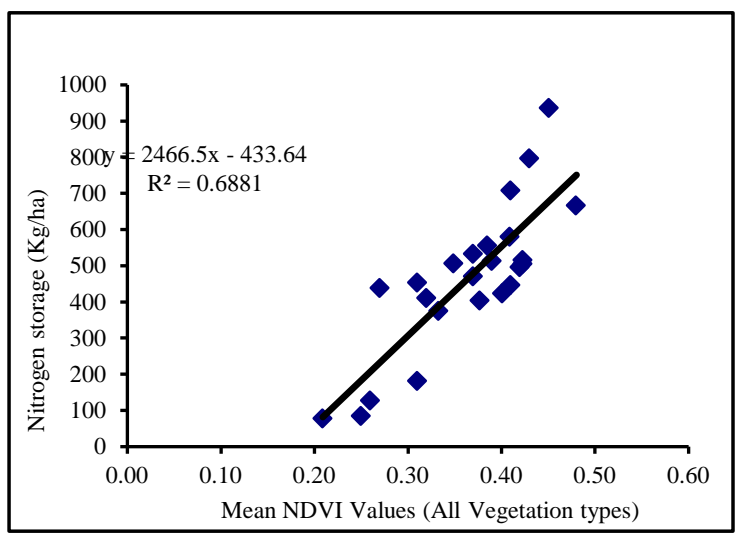

Figure 1: Relationship between NDVI and Nitrogen storage

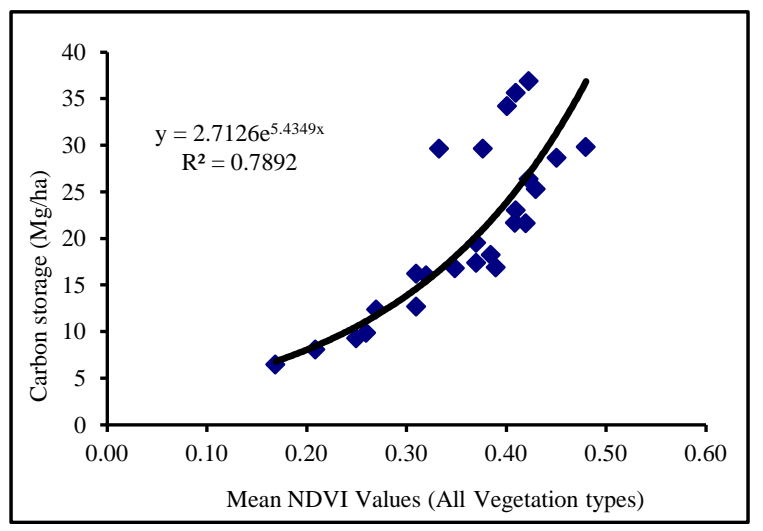

Figure 2: Relationship between NDVI and Carbon storage

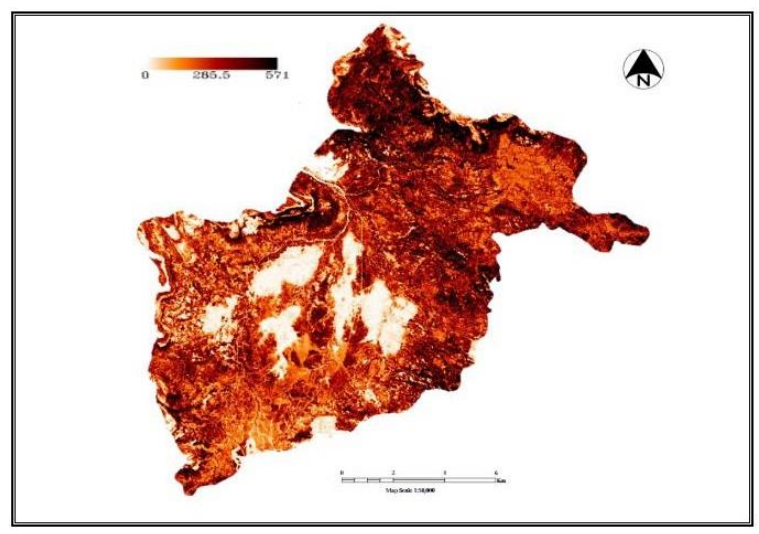

Plate 2: Nitrogen Storage map of dry tropical forests $(\mathrm{Kg} / \mathrm{ha})$

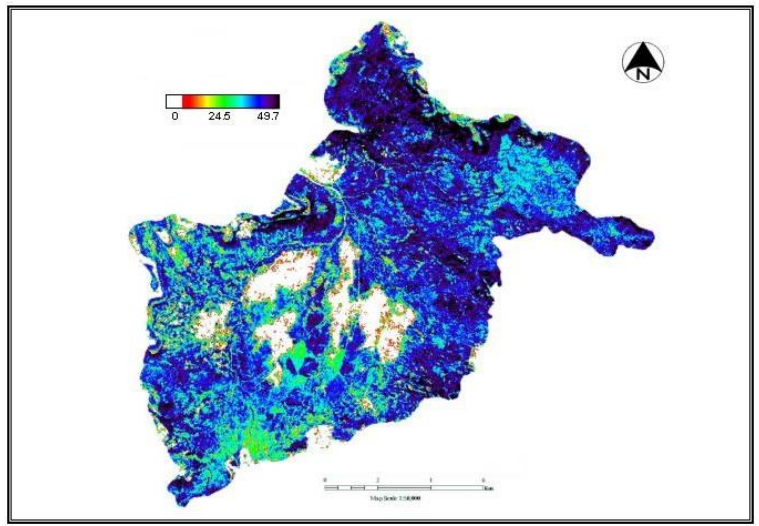

Plate 3: Carbon Storage map of dry tropical forests $(\mathrm{Mg} / \mathrm{ha})$

\section{3 $P$ and $K$ contents in different components of Overstorey, understorey and groundstorey vegetation}

Results on $\mathrm{P}$ and $\mathrm{K}$ contents of different components of Overstorey, understorey and groundstorey vegetation in various forest types are presented in Table 2. Analysis of variance indicated that significant differences in $\mathrm{P}$ and $\mathrm{K}$ contents were observed in different components of Overstorey, understorey and groundstorey vegetation among forest types. In general, the $\mathrm{P}$ and $\mathrm{K}$ contents followed the order: stem $>$ branch $>$ foliage $>$ root $>$ fine root. Total $\mathrm{P}$ content of vegetation (OS+US+GS) varied from $4.09 \mathrm{~kg} \mathrm{ha}^{-1}$ to 49.59 $\mathrm{kg} \mathrm{ha}^{-1}$ and $\mathrm{K}$ from $24.59 \mathrm{~kg} \mathrm{ha}^{-1}$ to $255.58 \mathrm{~kg} \mathrm{ha}^{-1}$ in different forest types. $\mathrm{P}$ and $\mathrm{K}$ were highest in Dense mixed forest followed by Teak forest and lowest in Degraded mixed forest. Sal mixed and Open mixed forest was statistically at par with each other for both P and K. Total P and K (OS+US+GS) also varied significantly in different forest types. For total vegetation $\mathrm{P}$, tree, shrub and herbs contributed from $86.55 \%$ to $95.62 \%, 4.25 \%$ to $12.71 \%$ and $0.12 \%$ to $0.73 \%$, respectively in different forests. Similarly for total K storage, trees, shrubs and herbs contributed from $80.88 \%$ to $92.09 \%$, $3.08 \%$ to $12.64 \%$ and $0.48 \%$ to $1.05 \%$, respectively in different forest types (Table 2).

Table 2: Total Phosphorus and Potassium content of overstorey, understorey and groundstorey $(\mathrm{Kg} / \mathrm{ha})$

\begin{tabular}{|l|c|c|c|c|c|c|c|c|}
\hline Forest type & \multicolumn{2}{|c|}{ Overstorey } & \multicolumn{3}{|c|}{ Understorey } & \multicolumn{2}{|c|}{ Groundstorey } & \multicolumn{2}{|c|}{ GT } \\
\hline & $\mathbf{P}$ & $\mathbf{K}$ & $\mathbf{P}$ & $\mathbf{K}$ & $\mathbf{P}$ & $\mathbf{K}$ & $\mathbf{P}$ & $\mathbf{K}$ \\
\hline Teak forest & 27.56 & 174.78 & 2.29 & 15.63 & 0.09 & 0.93 & 29.94 & 191.34 \\
\hline Sal mixed & 23.37 & 143.36 & 2.09 & 18.54 & 0.04 & 1.66 & 25.50 & 163.56 \\
\hline Dense mixed & 47.42 & 235.38 & 2.11 & 18.09 & 0.06 & 2.11 & 49.59 & 255.58 \\
\hline Open mixed & 24.05 & 124.61 & 2.36 & 18.22 & 0.04 & 1.31 & 26.45 & 144.14 \\
\hline $\begin{array}{l}\text { Degraded } \\
\text { mixed }\end{array}$ & 3.54 & 19.89 & 0.52 & 4.44 & 0.03 & 0.26 & 4.09 & 24.59 \\
\hline CD at 5\% & $\mathbf{3 . 2 0}$ & $\mathbf{3 . 5 2}$ & $\mathbf{0 . 0 7}$ & $\mathbf{0 . 0 7}$ & $\mathbf{0 . 0 1}$ & $\mathbf{0 . 0 1}$ & $\mathbf{4 . 2 3}$ & $\mathbf{5 . 0 2}$ \\
\hline
\end{tabular}




\subsection{Carbon sequestration and uptake of $\mathrm{N}$, $P$ and $K$ in different components of Overstorey, understorey and groundstorey vegetation}

Results on $\mathrm{C}$ accretion, $\mathrm{N}, \mathrm{P}$ and $\mathrm{K}$ uptake in different components of Overstorey, understorey and groundstorey in various forest types are presented in Table 3 and 4. C and nutrients uptake varied significantly in different components of Overstorey, understorey and groundstorey among forest types. In general, the $\mathrm{N}, \mathrm{P}, \mathrm{K}$ uptake and $\mathrm{C}$ accretion in vegetation followed the order: stem $>$ branch $>$ foliage $>$ fine root > root. Total $\mathrm{N}, \mathrm{P}, \mathrm{K}$ and $\mathrm{C}$ sequestration in vegetation (OS+US+GS) varied from 31.22 to $73.44 \mathrm{~kg} \mathrm{ha}^{-1} \mathrm{yr}^{-1}, 2.46$ to $6.64 \mathrm{~kg} \mathrm{ha}^{-1} \mathrm{yr}^{-1}, 10.58$ to $46.53 \mathrm{~kg} \mathrm{ha}^{-1} \mathrm{yr}^{-1}$ and 1490 to 5910 $\mathrm{kg} \mathrm{ha}^{-1} \mathrm{yr}^{-1}$ in different forest types (Table 3, 4). Nutrient uptake varied significantly in different forest types. N, P and $\mathrm{K}$ were highest in Open mixed forest, while $\mathrm{C}$ sequestration in Teak forest. Uptake of N, P and K were lowest in Degraded mixed forest. C sequestration was statistically at par with each other in Teak forest, Sal mixed and Open mixed forest. Overstorey contributed between $64.96-84.44 \%, 67.48-91.16 \%$ and $73.85-87.11 \%$, understorey between $12.14-29.95 \%, 8.46-$ $31.30 \%$ and $8.82-15.87 \%$ and groundstorey between $3.41-7.86$ $\%, 4.06-10.37 \%$ and $0.37-0.88 \%$ for total vegetation uptake of

Table 3: Uptake of $\mathrm{N}$ and $\mathrm{C}$ sequestration of overstorey, understorey and groundstorey in dry tropical forests $(\mathrm{Kg} / \mathrm{ha} / \mathrm{yr})$

\begin{tabular}{|c|c|c|c|c|c|c|c|c|c|c|c|c|}
\hline \multirow[t]{3}{*}{ Forest types } & \multicolumn{10}{|c|}{ Overstorey } & & \\
\hline & \multicolumn{2}{|c|}{ Stem } & \multicolumn{2}{|c|}{ Branch } & \multicolumn{2}{|c|}{ Foliage } & \multicolumn{2}{|c|}{ Root } & \multicolumn{2}{|c|}{ Fine root } & \multicolumn{2}{|c|}{ Total } \\
\hline & $\mathbf{N}$ & C & $\mathbf{N}$ & C & $\mathbf{N}$ & C & $\mathbf{N}$ & C & $\mathbf{N}$ & C & $\mathbf{N}$ & C \\
\hline Teak forest & 32.58 & 3160 & 3.49 & 230 & 2.73 & 260 & 2.92 & 1070 & 6.15 & 440 & 47.87 & 5160 \\
\hline Sal mixed & 20.14 & 1790 & 7.57 & 520 & 3.57 & 190 & 1.125 & 1070 & 5.84 & 370 & 38.245 & 3940 \\
\hline Dense mixed & 24.54 & 1610 & 7.56 & 490 & 4.39 & 240 & 2.17 & 700 & 6.28 & 340 & 44.94 & 3380 \\
\hline Open mixed & 24.35 & 1670 & 9.37 & 620 & 7.73 & 290 & 0.92 & 700 & 8.61 & 530 & 50.98 & 3810 \\
\hline Degraded mixed & 9.59 & 430 & 2.24 & 220 & 2.37 & 140 & 0.22 & 200 & 4.25 & 220 & 17.42 & 1210 \\
\hline CD at 5\% & 9.18 & 0.33 & 2.12 & 0.09 & 2.23 & 0.08 & 2.32 & 0.26 & 1.166 & 0.05 & 13.946 & 0.55 \\
\hline \multicolumn{13}{|c|}{ Understorey } \\
\hline Teak forest & 3.97 & 400 & - & - & 0.227 & 20 & 2.445 & 220 & - & - & 6.65 & 640 \\
\hline Sal mixed & 8.21 & 780 & - & - & 0.452 & 20 & 4.21 & 320 & - & - & 12.87 & 1120 \\
\hline Dense mixed & 7.47 & 480 & - & - & 0.405 & 20 & 2.75 & 270 & - & - & 10.63 & 770 \\
\hline Open mixed & 13.28 & 440 & - & - & 0.58 & 40 & 4.41 & 360 & - & - & 18.28 & 840 \\
\hline Degraded mixed & 6.035 & 230 & - & - & 0.77 & 10 & 2.54 & 160 & - & - & 9.35 & 400 \\
\hline CD at 5\% & 5.16 & 0.21 & & & 0.734 & 0.01 & 1.64 & 0.13 & & & 6.25 & 0.28 \\
\hline \multicolumn{13}{|c|}{ Groundstorey } \\
\hline Teak forest & 1.34 & 0.08 & - & - & - & - & 0.53 & 0.04 & - & - & 1.87 & 0.12 \\
\hline Sal mixed & 3.08 & 0.15 & - & - & - & - & 1.04 & 0.05 & - & - & 4.12 & 0.2 \\
\hline Dense mixed & 2.46 & 0.1 & - & - & - & - & 0.96 & 0.04 & - & - & 3.42 & 0.14 \\
\hline Open mixed & 3.16 & 0.17 & - & - & - & - & 1.02 & 0.06 & - & - & 4.18 & 0.23 \\
\hline Degraded mixed & 1.12 & 0.05 & - & - & - & - & 0.46 & 0.02 & - & - & 1.59 & 0.07 \\
\hline CD at $5 \%$ & 0.742 & 0.03 & - & & - & & 0.254 & 0.02 & - & & 0.79 & 0.05 \\
\hline
\end{tabular}

Table 4: Uptake of $\mathrm{P}$ and $\mathrm{K}$ of overstorey, understorey and groundstorey in dry tropical forests $(\mathrm{Kg} / \mathrm{ha} / \mathrm{yr})$

\begin{tabular}{|c|c|c|c|c|c|c|c|c|c|c|c|c|}
\hline \multirow[t]{3}{*}{ Forest types } & \multicolumn{12}{|c|}{ Overstorey } \\
\hline & \multicolumn{2}{|c|}{ Stem } & \multicolumn{2}{|c|}{ Branch } & \multicolumn{2}{|c|}{ Foliage } & \multicolumn{2}{|c|}{ Root } & \multicolumn{2}{|c|}{ Fine root } & \multicolumn{2}{|c|}{ Total } \\
\hline & $\mathbf{P}$ & $\mathbf{K}$ & $\mathbf{P}$ & $\mathbf{K}$ & $\mathbf{P}$ & $\mathbf{K}$ & $\mathbf{P}$ & $\mathbf{K}$ & $\mathbf{P}$ & $\mathbf{K}$ & $\mathbf{P}$ & $\mathbf{K}$ \\
\hline Teak forest & 2.085 & 7.69 & 0.29 & 5.81 & 0.43 & 4.3 & 1.075 & 0.77 & 1.087 & 5.24 & 4.94 & 23.8 \\
\hline Sal mixed & 1.945 & 5.28 & 0.85 & 2.5 & 0.697 & 3.26 & 0.092 & 0.26 & 0.932 & 4.96 & 4.517 & 16.24 \\
\hline Dense mixed & 1.953 & 7.73 & 0.683 & 3.72 & 0.88 & 9.36 & 0.218 & 1.34 & 0.127 & 5.18 & 3.855 & 27.33 \\
\hline Open mixed & 2.055 & 7.14 & 0.99 & 5.62 & 1.817 & 19.68 & 0.085 & 0.52 & 0.22 & 5.72 & 5.168 & 38.67 \\
\hline Degraded mixed & 0.858 & 1.92 & 0.17 & 0.65 & 0.42 & 1.72 & 0.02 & 0.05 & 0.065 & 3.7 & 1.55 & 8.03 \\
\hline CD at 5\% & 0.947 & 3.22 & 0.225 & 1.17 & 0.698 & 7.73 & 0.02 & 1.16 & 0.178 & 1.12 & 1.629 & 10.18 \\
\hline \multicolumn{13}{|c|}{ Understorey } \\
\hline Teak forest & 0.535 & 1.19 & - & - & 0.085 & 0.8 & 0.145 & 0.42 & - & - & 0.76 & 0.044 \\
\hline Sal mixed & 0.792 & 2.1 & - & - & 0.042 & 0.56 & 0.23 & 0.8 & - & - & 1.065 & 0.048 \\
\hline Dense mixed & 0.597 & 2.32 & - & - & 0.032 & 0.7 & 0.11 & 0.35 & - & - & 0.74 & 0.03 \\
\hline Open mixed & 1.12 & 3.81 & - & - & 0.047 & 1.1 & 0.258 & 0.84 & - & - & 1.425 & 0.047 \\
\hline Degraded mixed & 0.265 & 0.97 & - & - & 0.06 & 0.32 & 0.125 & 0.39 & - & - & 0.45 & 0.022 \\
\hline CD at 5\% & 0.416 & 1.23 & - & - & 0.0859 & 5.31 & 0.094 & 0.32 & - & - & 0.443 & 0.0194 \\
\hline \multicolumn{13}{|c|}{ Groundstorey } \\
\hline Teak forest & 0.029 & 0.75 & - & - & - & - & 0.015 & 0.37 & - & - & 0.044 & 1.11 \\
\hline Sal mixed & 0.037 & 1.72 & - & - & - & - & 0.01 & 0.56 & - & - & 0.048 & 2.28 \\
\hline Dense mixed & 0.025 & 1.4 & - & - & - & - & 0.01 & 0.52 & - & - & 0.03 & 1.92 \\
\hline Open mixed & 0.037 & 1.54 & - & - & - & - & 0.01 & 0.57 & - & - & 0.047 & 2.11 \\
\hline Degraded mixed & 0.017 & 0.64 & - & - & - & - & 0.005 & 0.23 & - & - & 0.022 & 0.87 \\
\hline CD at 5\% & 0.01 & 0.38 & - & - & - & - & 0.02 & 0.14 & - & - & 0.0194 & 0.42 \\
\hline
\end{tabular}


N, P and K, respectively. Similarly for total vegetation C, Overstorey, understorey and groundstorey contributed between $68.45-87.14 \%, 10.65-26.84 \%$ and $1.86-5.18 \%$, respectively (Table 3,4). Lodhiyal et al. (2002) studied that the net uptake of nutrients was $64-117 \mathrm{~kg} \mathrm{ha}^{-1} \mathrm{yr}^{-1}$ for N, 6$11 \mathrm{~kg} \mathrm{ha}^{-1} \mathrm{yr}^{-1}$ for $\mathrm{P}$ and 29-54 kg ha-1 $\mathrm{yr}^{-1}$ for $\mathrm{K}$. An estimate for net uptake of $\mathrm{N}, \mathrm{P}, \mathrm{K}$ and $\mathrm{C}$ accretion in the present study is compared with certain other forests. Estimates of nutrient uptake for tropical humid forests (Golley et al., 1975) are 136-430 for N, 11-25 for P and 94$255 \mathrm{~kg} \mathrm{ha}^{-1} \mathrm{yr}^{-1}$ for $\mathrm{K}$. The mean uptake of nutrients in the present study for $\mathrm{N}$ and $\mathrm{P}$ is towards the lower end of the above range while $\mathrm{K}$ uptake is distinctly lower compared to values cited above. In general the relative share of shrubs in the total nutrient uptake ranged between $10.65-26.84 \%$ and that of herbs between $1.86-5.18 \%$.

The total carbon storage in the present study for different forest types varied from 6.96 to $47.75 \mathrm{Mg} \mathrm{C} / \mathrm{ha}$.. The estimates of carbon storage of this forests are with in the range and comparable to carbon storage in tropical forests in different localities (Schroeder, 1992; Haripriya, 2000; Shepherd and Montagnini, 2001; Narris, 2001; He et al., 2002; Swamy and Puri, 2002.. Haripriya (2000) reported 97.3 $\mathrm{Mg} \mathrm{ha}^{-1}$ above ground biomass and $48.3 \mathrm{Mg} \mathrm{C}^{-}$ ${ }^{1}$ carbon storage for tropical deciduous forests of India. Similarly an above ground biomass of $53.9 \mathrm{Mg} \mathrm{ha}^{-1}$ and Carbon storage of $26.95 \mathrm{Mg} \mathrm{C}^{-1}$ were found in Teak forests, whereas Sal forests recorded $68.2 \mathrm{Mg} \mathrm{ha}^{-1}$ of biomass and 34.1 $\mathrm{Mg} \mathrm{C}$ ha $^{-1}$ above ground Carbon storage.

\subsection{Turnover of nutrients in standing vegetation}

The estimated turnover time of nutrients for trees and shrubs in different forest types are presented in Table 5. The turnover time of different nutrients for overstorey varied from 4.96-11.67 yrs for N, 5.49-14.01 yrs for P, 2.99-12.73 yrs for K and 5.79-13.07 yrs for C. The turnover time for different nutrients in the understorey varied from 1.83-3.65 yrs for N, 2.34-3.82 yrs for P, 2.05-3.39 yrs for $\mathrm{K}$ and 2.76-4.67 yrs for $\mathrm{C}$ in different forest types.

Table 5: Turnover time for different nutrients in standing vegetation of different forest types (years)

\begin{tabular}{|l|c|c|c|c|c|c|c|c|}
\hline \multirow{2}{*}{$\begin{array}{c}\text { Fores } \\
\text { t type }\end{array}$} & \multicolumn{4}{|c|}{ Overstorey } & \multicolumn{4}{c|}{ Understorey } \\
\cline { 2 - 9 } & $\mathbf{N}$ & $\mathbf{P}$ & $\mathbf{K}$ & $\mathbf{C}$ & $\mathbf{N}$ & $\mathbf{P}$ & $\mathbf{K}$ & $\mathbf{C}$ \\
\hline Teak & 7.3 & 6.72 & 6.28 & 7.31 & 3.45 & 2.99 & $\begin{array}{c}2.5 \\
1\end{array}$ & $\begin{array}{c}3.6 \\
1\end{array}$ \\
forest & 9 & & & & & & 3.3 & 2.7 \\
\hline $\begin{array}{l}\text { Sal } \\
\text { mixed }\end{array}$ & 10. & 10.5 & 9.64 & 7.53 & 3.65 & 3.82 & $\begin{array}{c}3.3 \\
9\end{array}$ \\
\hline $\begin{array}{l}\text { Dense } \\
\text { mixed }\end{array}$ & $\begin{array}{c}11 . \\
6\end{array}$ & 14.0 & 12.7 & 13.1 & 2.48 & 2.47 & $\begin{array}{c}2.0 \\
5\end{array}$ & $\begin{array}{c}2.9 \\
5\end{array}$ \\
\hline $\begin{array}{l}\text { Open } \\
\text { mixed }\end{array}$ & $\begin{array}{c}6.0 \\
2\end{array}$ & 8.96 & 8.23 & 9.62 & 2.40 & 2.71 & $\begin{array}{c}2.2 \\
7\end{array}$ & $\begin{array}{c}4.6 \\
7\end{array}$ \\
\hline $\begin{array}{l}\text { Degra } \\
\text { ded } \\
\text { mixed }\end{array}$ & 4.9 & 5.49 & 2.99 & 5.79 & 1.83 & 2.34 & $\begin{array}{c}2.5 \\
6\end{array}$ & $\begin{array}{c}3.1 \\
7\end{array}$ \\
\hline
\end{tabular}

\section{CONCLUSION}

The study indicated that satellite remote sensing and GIS techniques were proved as most reliable tools for the characterisation of land use, vegetation structure, biomass production, $\mathrm{C}$ and nutrient storage of dry tropical ecosystems of Chhattisgarh, India. The study reflects that dry tropical forests of Chhattisgarh are not ecologically as rich as other dry tropical forests of the world in terms of structure, diversity, biomass, NPP, C, and nutrient (N, P and $\mathrm{K}$ ) storage. The increasing biotic interferences are degrading these forests and resulting in poor density and also lowering the number of trees in higher diameter classes, consequently affecting the standing biomass and carbon storage in the forests.

\section{REFERENCES}

Brown, S. \& knight, P. 1994. Assessing Learners in Higher Education, London: Kogan Page.

Brown, S., Lugo A.E., 1982. The storage and production of organic matter in tropical forests and their role in global carbon cycle. Biotrop. 14, 161-187.

Chaturvedi, O.P. and Singh, J.S. 1987. The structure and function of pine forest in central Himalayas. Dry matter dynamics. Annals of Botany, 60: 237-252.

Feeler, M. C. 1980. Biomass and nutrient distribution in two eucalypt forest ecosystems. Australian Journal of Ecology. 5: 309-333.

Field, C. B. and Kaduk, J. 2004. The carbon balance of an old-growth forest: Building across approaches. Ecosystems, 7:525-533.

Foody, G.M., Paulbinskas, G., Lucas, R.M., Curran, P.J. and Honzak, M. 1996. Identifying terrestrial carbon sinks : classification of successional stages in regenerating tropical forest from landsat TM data. Remote Sensing of Environment, 55: 205-216.

FSI, 1995. Extent, Composition, Density, Growing stock and Annual increment of Indian. Forest Survey of India (Ministry of Forests and Environment) Govt. of India Press, Dehradun-248195.

Golley, F. B., J. T. McGinnis, R. G. Clements, G. I. Child \&M. J. Duever. 1975. Mineral cycling in a tropical moist forest ecosystem. University of Georgia Press, Athens, Georgia.

Haripriya, G. S. 2000. Estimates or biomass in Indian forests, Biomass and Bio-energy, 19 (4): 245-258. 
He, C, Wang, S., Xu, J. and Zhou, C. 2002. Using remote sensing to estimate the change of carbon storage: A case study in the estuary of yellow river delta, Int. J. R. S., 23 (8): 1565-1580.

Jackson, M. L. 1958. Soil Chemical Analysis: PrenticeHall, Englewood Cliffs, N.J., 498 pp.

Jha, C.S. and Singh, J.S. 1990. Composition and dynamics of dry tropical forest in relation to soil texture. Journal of Vegetation Science, 1:609-614.

King, A.W., Wilfred, M., Post, M. and Wullschleger, S.D. 1997. The potential response of terrestrial Carbon storage to changes in climate and atomospheric $\mathrm{CO}_{2}$. Climatic Change, 35: 199-227.

Lodhiyal, L. S. And Lodhiyal, N. 1997. Nutrient cycling and nutrient use efficiency in short rotation, high density central Himalayan Tarai poplar plantations, Annals of Botany. 79: 517-527.

Lodhiyal, L. S., Singh, R. P. And Sing. P. 1995. Structure and function of an age series of poplar plantations in central Himalayan. II Nutrient dynamics. Annals of Botany. 76: 201-210.

Lodhiyal, N., Lodhiyal, L. S., and Pangtey, Y. P. S., 2002. Structure and function of Shisham forests in Central Himalaya, India: dry matter dynamics. Annals of Botany $89,41-54$

Melillo, J.M., McGuire, A.D., Kiocklighter, D.W., Moore B III, Vorosmarty, C.J. and Schlolss, A.I.1993. Global climate change and terrestrial Net Primary Production. Nature, 363: 234-240.

Negi JDS, Chauhan PS \& Negi M. 2003. Evidences of climate change and its impact on structure and function of forest ecosystems in and around doon vally. Indian Forester, 129 (6): 757-769.

Olsen, S.R., Cole, C.V., Watanabe, F.S. and Dean, L.A., 1954. Estimation of available phosphorus in soils by extraction with sodium bicarbonate. USDA Circular 939.

Ravan, S.A. 1994. Ecological analysis of vegetation from satellite remote sensing at Madhav National Park Sivapuri (M.P.). Ph.D. Thesis, HNB Garhwal University, Srinagar, India.

Rawat, Y. S. And Singh, J. S. 1988. Structure and function of oak in central Himalayan. II Nutrient dynamics. Annals of Botany. 62: 413-427.
Roy, P.S., Singh, S. and Porwal, Mc. 1993. Characterization of ecological parameters in tropical forest community - a remote sensing approach. Journal of Indian Society of Remote Sensing, 21(3): 127-148.

Schroeder, P. 1992. Carbon storage potential of short rotation tropical tree plantations. Forest Ecology and Management, 50: 31-41.

Shepherd, D. and Montagnini, F. 2001. Above ground carbon sequestration potential in mixed and pure tree plantations in the humid tropics. Journal of tropical forest Science, 13(3): 450-459.

Singh, L. and Singh, J.S. 1991. Species structure, dry matter dynamics and carbon flux of a dry tropical forest in India. Annals of Botany, 68: 263-273.

Soil Survey Staff, 1960. Soil classification. A comprehensive system- $7^{\text {th }}$ Approximation. Soil Conservation Services, United State Department of Agriculture. US Government Printing Office, Washington, DC.

Stoms, D. M. and Estes, J. E. 1993. A remote sensing research agenda for mapping \& monitoring biodiversity. International Journal of Remote Sensing, 14: 1839-1860.

Swamy, S.L. 1998. Estimation of Net Primary Productivity (NPP) in an Indian tropical evergreen forest using Remote Sensing data. Ph.D. Thesis, Jawaharlal Nehru Technology University, Hyderabad.

Swamy, S.L. and Puri, S. 2002. Growth, biomass, carbon storage and nutrient distribution in Gmelina arborea Roxb. Stands on red lateritic soils in central India. Bioresource Technology.

Verstrate, M.M. and Pinty, B. 1991. The potential contribution of satellite remote sensing to the understanding of arid lands processes vegetation, 91:59-72. 